\title{
Development and application of a triplex real-time PCR assay for simultaneous detection of avian influenza virus, Newcastle disease virus, and duck Tembusu virus
}

\author{
Xiyu Zhang ${ }^{1,2}$, Ming Yao ${ }^{1}$, Zhihui Tang ${ }^{1}$, Daning $X u^{3}$, Yan Luo ${ }^{4}$, Yunfei Gao ${ }^{5}$ and Liping Yan ${ }^{1,2^{*}}$ (1)
}

\begin{abstract}
Background: Pathogens including duck-origin avian influenza virus (AIV), duck-origin Newcastle disease virus (NDV) and duck Tembusu virus (DTMUV) posed great harm to ducks and caused great economic losses to the duck industry. In this study, we aim to develop a triplex real-time polymerase chain reaction (PCR) assay to detect these three viruses as early as possible in the suspicious duck flocks.

Results: The detection limit of the triplex real-time PCR for AIV, NDV, and DTMUV was $1 \times 10^{1} \mathrm{copies} / \mathrm{\mu L}$, which was at least 10 times higher than the conventional PCR. In addition, the triplex assay was highly specific, and won't cross-react with other duck pathogens. Besides, the intra-day relative standard deviation and inter-day relative standard deviation were lower than $4.44 \%$ for these viruses at three different concentrations. Finally, a total of 120 clinical samples were evaluated by the triplex real-time PCR, the conventional PCR and virus isolation, and the positive rates for these three methods were 20.83, 21.67, 19.17\%, respectively. Taking virus isolation as the gold standard, the diagnostic specificity and positive predictive value of the three viruses were all above $85 \%$, while the diagnostic sensitivity and negative predictive value of the three viruses were all $100 \%$.

Conclusion: The developed triplex real-time PCR is fast, specific and sensitive, and is feasible and effective for the simultaneous detection of AIV, NDV, and DTMUV in ducks.
\end{abstract}

Keywords: Real-time PCR, AIV, NDV, DTMUV, Ducks, Clinical detection

\section{Background}

China is the largest duck producer of the world, accounting for more than half of the world's total duck meat stock. During the breeding of ducks, virus infection is a serious problem and has caused huge economic loss

\footnotetext{
* Correspondence: yanliping@njau.edu.cn

'College of Veterinary Medicine, Nanjing Agricultural University, Nanjing 210095, China

${ }^{2} \mathrm{MOE}$ Joint International Research Laboratory of Animal Health and Food Safety, Nanjing Agricultural University, Nanjing 210095, China

Full list of author information is available at the end of the article
}

to the waterfowl industry, among which, duck-derived avian influenza virus (AIV), duck-derived Newcastle disease virus (NDV), and duck Tembusu virus (DTMUV) are the most common virus. AIV belongs to influenza $\mathrm{A}$ virus of Orthomyxoviridae and has many serotypes, most of which have been detected in domestic ducks and wild ducks. The high-pathogenicity subtypes such as $\mathrm{H} 5$ and H7 are highly virulent to ducks of various ages and breeds [1-3]. Although the low-pathogenicity subtypes such as H3, H6, H9 and H10 are often detected in duck

C C The Author(s). 2020 Open Access This article is licensed under a Creative Commons Attribution 4.0 International License, which permits use, sharing, adaptation, distribution and reproduction in any medium or format, as long as you give appropriate credit to the original author(s) and the source, provide a link to the Creative Commons licence, and indicate if changes were made. The images or other third party material in this article are included in the article's Creative Commons licence, unless indicated otherwise in a credit line to the material. If material is not included in the article's Creative Commons licence and your intended use is not permitted by statutory regulation or exceeds the permitted use, you will need to obtain permission directly from the copyright holder. To view a copy of this licence, visit http://creativecommons.org/licenses/by/4.0/ The Creative Commons Public Domain Dedication waiver (http://creativecommons.org/publicdomain/zero/1.0/) applies to the data made available in this article, unless otherwise stated in a credit line to the data. 
flocks [4-7], ducks often show asymptomatic infection [8]. However when these viruses spread to other birds through polluted water or excreta, they could cause large scale outbreak. NDV belongs to Avulavirus of Paramyxoviridae, which is highly pathogenic and considered to be a notifiable disease by the World Organisation for Animal Health. Waterfowls are considered as the potential reservoirs for NDV. Since 1997, NDV infection occurred frequently in ducks all over China, causing devastating economic losses [7, 9]. DTMUV belongs to the genus of flavivirus in Flavivirudae and mainly affects laying ducks. DTMUV can cause egg-laying reducion, death, and reduced feed intake in the infected ducks. The morbidity can reach $90 \%$, and the mortality rate can vary from 5 to $30 \%$ when the ducklings are infected with DTMUV [10]. It is worth noting that mixed infection by these three viruses often occurs clinically, and the clinical symptoms of the sick ducks are similar after infected with these viruses, such as thin stools, reduced egg production, fever, and respiratory symptoms, and neurological symptoms. Therefore, establishment of a laboratory diagnostic method for these three viruses is necessary.

At present, the common methods used for detecting these viral infections include virus isolation and identification, serological detection, immuno-electron microscopy, enzyme-linked immunosorbent assay (ELISA) and polymerase chain reaction (PCR) techniques [11-15]. Virus isolation and identification is a confirmation method for AIV, NDV and DTMUV detection [16-19]. However, it requires special facilities, skilled personnel and fresh specimens with viable viruses. Besides, these methods are time-consuming and labor insensitive [20, 21]. Immunoassay-based methods, such as ELISA, have been widely used [22]. However, the difficulty of developing highly specific antibodies and the high falsepositive rate limit their application [23]. Although immuno-electron microscopy is an accurate and confirmative method for virus detection [24-26], it is not suitable for clinical diagnosis due to the requirement of complex instruments and a large number of viruses [20].

Nowadays, PCR technology has been accepted as a new gold standard for molecular diagnosis of different pathogens [16, 27-29] because of its high speed, specificity, and sensitivity. So far, conventional PCR methods have been developed for these viruses [30-32]. However, after the amplification of the target fragment, agarose gel electrophoresis was required to analyze the results, which potentially increases the probability of falsepositive and is not suitable for clinical rapid detection. As the second-generation PCR technology emerging in 1990s, real-time PCR combines PCR amplification and electrophoresis determination into one step, which saves time and manpower, and reduces the risk of residual contamination. In this study, a TaqMan triplex real-time PCR method was developed and optimized, after validation, it was applied to the real sample analysis. The results showed that developed method is rapid, specific and sensitive, which is feasible and effective for simultaneous detection of AIV, NDV, and DTMUV in ducks.

\section{Result \\ Optimization of the triplex real-time PCR assay}

The triplex real-time PCR method was first optimized by D-optimal design and 16 runs were performed in a randomized batch (in triplicate measurements). Taking AIV as an example, the three-dimension response surface curves are shown in Fig. 1A. The 4D plots further illustrated the interaction between the three factors (Fig. 1B). The results show that low $\mathrm{Ct}$ values can be obtained at the annealing temperature of $53-55.5^{\circ} \mathrm{C}$, the probe concentration of $0.05-0.125 \mu \mathrm{M}$, and the primer concentration of $0.38-0.55 \mu \mathrm{M}$. Figure 2 showed the effect of different annealing temperature as well as the concentration of probes and primers on fluorescence signal. As shown in the figure, the fluorescence signal increased with the increase of probe concentration (Fig. 2A, B, C) and the decrease of annealing temperature (Fig. 2G, H, I). When the primer concentration was in the range of $0.4-0.6 \mu \mathrm{M}$, the fluorescence intensity was higher and the difference was not significant (Fig. 2D, E, F). Considering the economic and practical factors, the parameters were selected as follows: annealing temperature at $54^{\circ} \mathrm{C}$, primer concentration at $0.5 \mu \mathrm{M}$ and probe concentration at $0.1 \mu \mathrm{M}$. The amplification curve of these three viruses with optimal parameters was shown in Additional file 1.

\section{Specificity test}

The triplex real-time PCR assay was used to amplify other common duck pathogens, including Avian paramyxovirus 4 (APMV-4), Avian paramyxovirus 6 (APMV-6), Avian paramyxovirus 8 (APMV-8), Avian paramyxovirus 9 (APMV-9), Clostridium perfringens (C.perfringens), duck hepatitis A virus (DHAV), duck enteritis virus (DEV), goose parvovirus (GPV), fowl adenovirus (FAdV), duck egg drop syndrome virus (EDSV), Escherichia coli (E.coli), Pasteurella multocida (P. multocida), Riemerella anatipestifer (RA) and Salmonella (SE). As speculated, only strong fluorescence signals were obtained for AIV, NDV, and DTMUV. The signals for other samples and negative controls were below the baseline detection levels (Fig. 3), indicating that the triplex real-time PCR method has good specificity.

\section{Sensitivity test}

Serial dilutions of the standard plasmids (from $1 \times 10^{7}$ copies $/ \mu \mathrm{L}$ to $1 \times 10^{1}$ copies $/ \mu \mathrm{L}$ ) were used to determine the sensitivities of the triplex real-time PCR assay, 


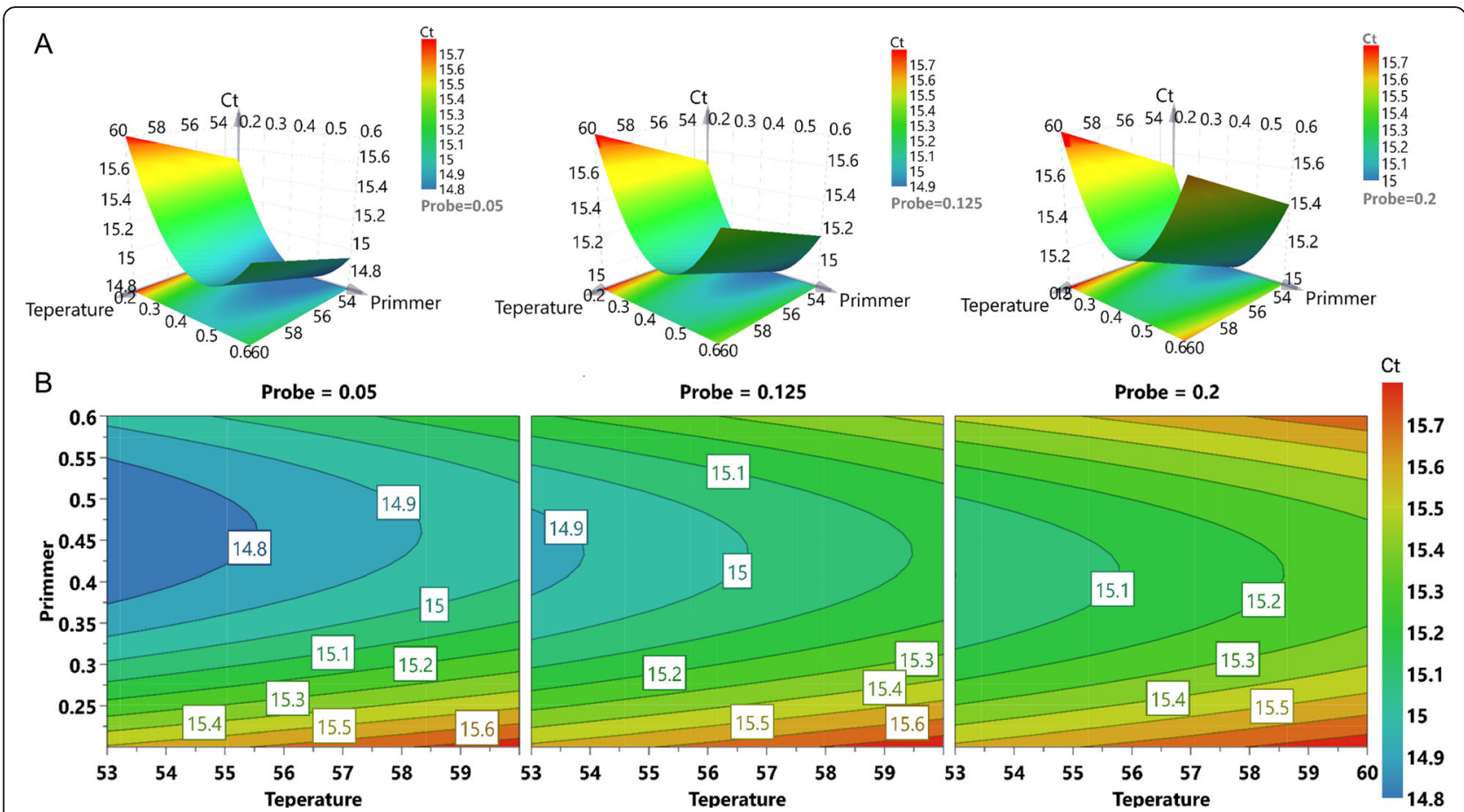

Fig. 1 Response surface plots for AIV. A: Different combinations of three factors to form the three-dimension response surface curves. B: 4D plots indicated the interaction between the three factors

uniplex real-time PCR (Table 1) and conventional PCR. The standard curve was generated for each virus by 10fold serial dilutions. As shown in Table 1 and Fig. 4, the detection limits of triplex and uniplex real-time PCR were $1 \times 10^{1}$ copies $/ \mu \mathrm{L}$ for these three viruses, while the detection limit for the conventional PCR was $1 \times 10^{2}$ copies/ $\mu \mathrm{L}$ for AIV, NDV and DTMUV. That is, the detection limits of real-time PCR were 10 times better than that of the conventional PCR method. The standard curves and amplification curves for the triplex assays were shown in Fig. 5. The SD values were analyzed in triplicate by real-time PCR, which revealed that the results of the assays were reliable and accurate (Table 1).

\section{Repeatability and reproducibility of the real-time PCR}

The intra- and inter-assay CVs were evaluated at the conventration of $1 \times 10^{7}, 1 \times 10^{5}$ and $1 \times 10^{3}$ copies/ $\mu \mathrm{L}$, respectively. The results showed that the intra-assay $\mathrm{CV}$ were below $2.19 \%$, while that of inter-assay CV were below $4.44 \%$ (Table 2). Therefore, the triplex real-time PCR assay developed in this study is highly reliable and accurate.

\section{Co-infection models and clinical sample detection}

As shown in Table 3, the method could detect three viruses at the combinations of different concentrations. Furthermore, the $\mathrm{Ct}$ value of the co-infection models also satisfied the linear standard, indicating its applicability in virus quantification during the co-infection.

Finally, a total of 120 samples were examined (Table 4). As shown in the result, 25 samples (17 of AIV, 7 of NDV, 3 of DTMUV) were determined positive by the triplex real-time PCR method, while 26 samples (18 of AIV, 7 of NDV, 3 of DTMUV) were positive determined by conventional PCR method. However, only 23 samples could be detected by virus isolation (16 of AIV, 6 of NDV, 3 of DTMUV). The virus positive rate were $20.83 \%$ (25/120), 21.67\% (26/120) and 19.17\% (23/120) as detected by triplex Real-time PCR, conventional PCR, and virus isolation. All positive results were verified by sequencing. The 23 positive samples determined by the virus isolation were confirmed by the real-time PCR. However, sample No.17 and No.27, which were determined as AIV positive and NDV positive respectively by real-time PCR, were negative by virus isolation. Furthermore, 2 samples, which were co-infected with AIV and NDV, could be detected by these three methods.

The diagnostic performance of real-time PCR and conventional PCR were calculated using the virus isolation as reference (Table 5). In the detection of AIV and NDV, the diagnostic specificity and negative predictive value of the two methods were all above 95\%. However, the diagnostic sensitivity and positive predictive value of real-time PCR were better than that of conventional 


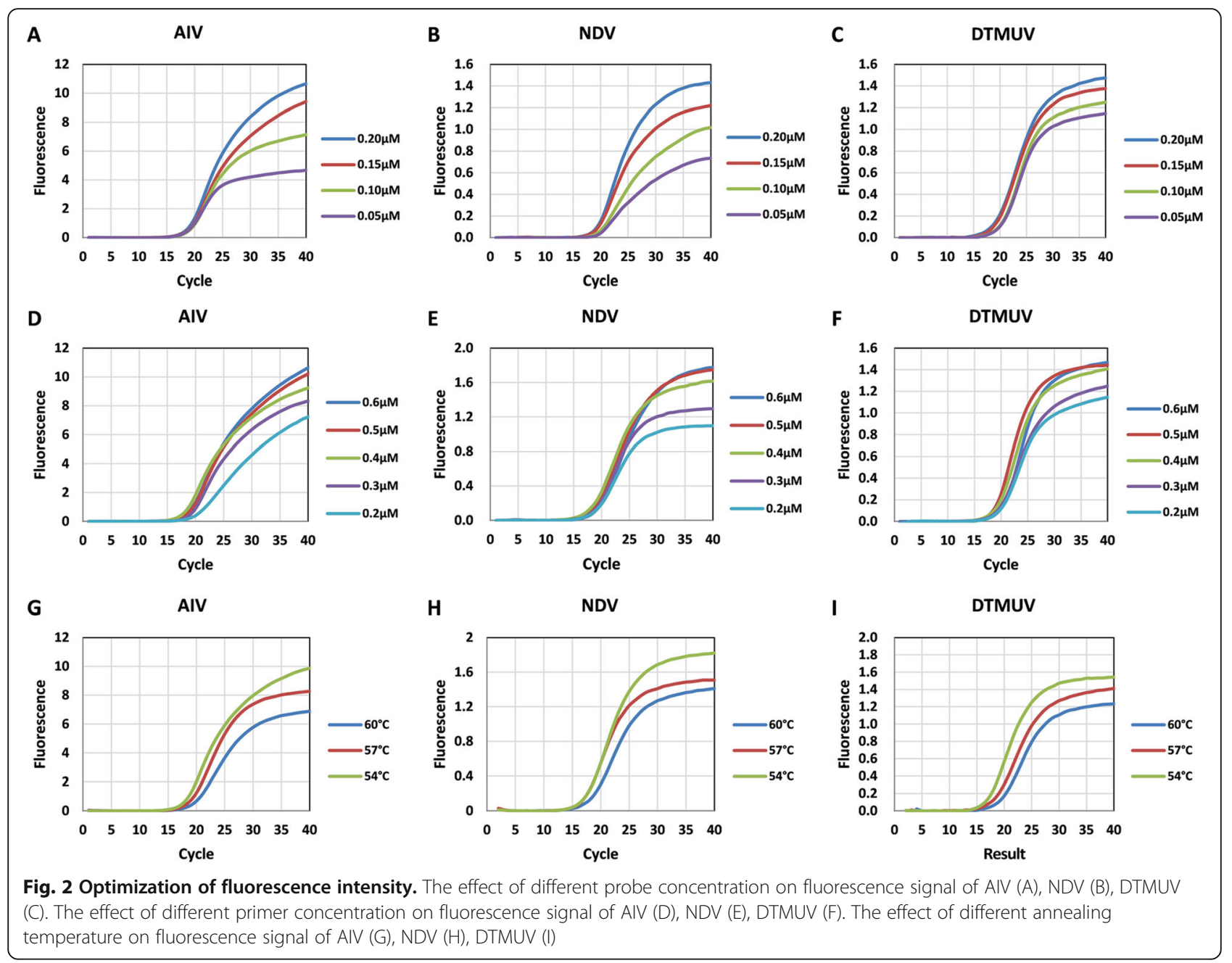

PCR. Furthermore, these two methods have excelent

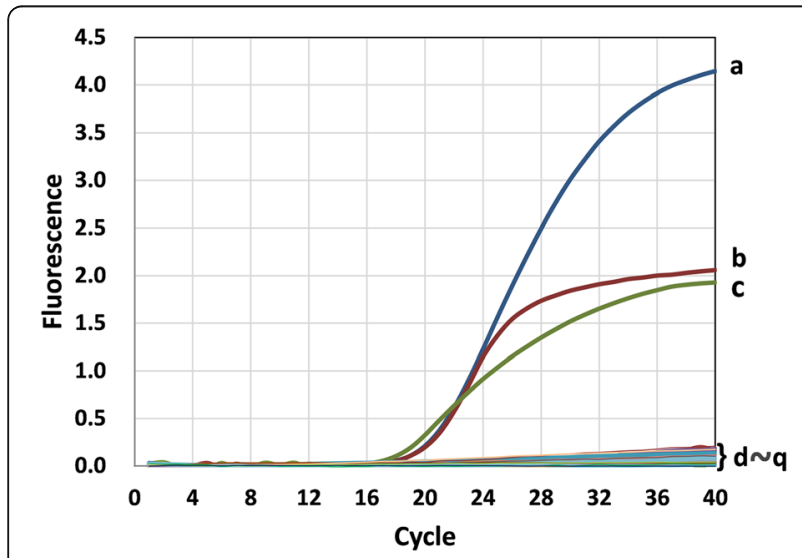

Fig. 3 Specificity of the triplex real-time PCR assay. The assay was used to amplify AIV, NDV, DTMUV and other pathogens. Only a. pMD-AIV, b. pMD-NDV and c. pMD-DTMUV templates produced positive signals. d. DHAV, e. DEV, f. GPV, g. FAdV, h. EDSV, i. APMV-4, j. APMV-6, k. APMV-8, I. APMV-9, m. E.coli, n. SE, o. RA, p. P. multocida, q. C.perfringens diagnostic performance in the detection of DTMUV, both of which were $100 \%$.

\section{Discussion}

For its high specificity and sensitivity, real-time PCR has shown great advantages in the rapid detection of the pathogen [28]. However, the multiplex real-time PCR method to simultaneous detection of AIV, NDV and DTMUV viruses in ducks has not been reported. In this study, we aim to develop a triplex real-time PCR assay that can simultaneously detect these viruses in clinical samples.

Primers and probes are particularly important for the development of a novel triplex real-time PCR method, which determines its sensitivity and specificity. Therefore, in order to find the optimal primers and probes, we made an initial comparison of the sequences of the three viruses, especially the epidemic strains in recent years, and design the primers and probes in the conservative region of each virus (Table 6), the specificity of the primers and probes were verified by BLAST in NCBI. In 
Table 1 Sensitivity and standard curves of the triplex real-time PCR assay

\begin{tabular}{|c|c|c|c|c|c|c|}
\hline \multirow{2}{*}{$\begin{array}{l}\text { Number } \\
\text { of DNA } \\
\text { copies } \\
\text { (copies/ } \\
\mu \mathrm{L} \text { ) } \\
\end{array}$} & \multicolumn{3}{|c|}{$\begin{array}{l}\text { triplex real-time PCR Ct Value } \\
\text { (mean } \pm \text { SD) }\end{array}$} & \multicolumn{3}{|c|}{$\begin{array}{l}\text { Uniplex real-time PCR Ct Value } \\
\text { (mean } \pm \mathrm{SD} \text { ) }\end{array}$} \\
\hline & AIV & NDV & DTMUV & AIV & NDV & DTMUV \\
\hline $1 \times 10^{7}$ & $13.61 \pm 0.20$ & $14.50 \pm 0.14$ & $14.30 \pm 0.33$ & $13.93 \pm 0.07$ & $15.01 \pm 0.17$ & $14.68 \pm 0.41$ \\
\hline $1 \times 10^{6}$ & $16.42 \pm 0.21$ & $18.00 \pm 0.37$ & $17.87 \pm 0.09$ & $16.31 \pm 0.15$ & $18.22 \pm 0.26$ & $18.05 \pm 0.04$ \\
\hline $1 \times 10^{5}$ & $20.33 \pm 0.22$ & $21.39 \pm 0.08$ & $21.44 \pm 0.09$ & $20.32 \pm 0.04$ & $22.26 \pm 0.11$ & $21.24 \pm 0.16$ \\
\hline $1 \times 10^{4}$ & $23.02 \pm 0.52$ & $24.41 \pm 0.16$ & $24.99 \pm 0.05$ & $23.04 \pm 0.44$ & $24.71 \pm 0.16$ & $24.73 \pm 0.43$ \\
\hline $1 \times 10^{3}$ & $26.01 \pm 0.37$ & $28.04 \pm 0.35$ & $28.30 \pm 0.08$ & $25.84 \pm 0.20$ & $27.74 \pm 0.53$ & $27.78 \pm 0.01$ \\
\hline $1 \times 10^{2}$ & $29.55 \pm 0.15$ & $30.45 \pm 0.36$ & $31.19 \pm 0.65$ & $29.30 \pm 0.30$ & $30.78 \pm 0.47$ & $31.12 \pm 0.12$ \\
\hline $1 \times 10^{1}$ & $32.42 \pm 0.68$ & $33.34 \pm 0.71$ & $33.29 \pm 0.86$ & $32.98 \pm 0.34$ & $33.85 \pm 0.68$ & $33.38 \pm 0.60$ \\
\hline
\end{tabular}

Serial 10 -fold dilutions from $1 \times 10^{7}$ to $1 \times 10^{1}$ copies of pMD-AIV, pMD-NDV, pMD-DTMUV were used as templates to determine the standard curve of the triplex real-time PCR and for uniplex real-time PCR. Each dilution was performed in triplicate for the assays

$\mathrm{Ct} \leq 34$ was considered positive for AIV, $\mathrm{Ct} \leq 35$ was considered positive for NDV and DTMUV

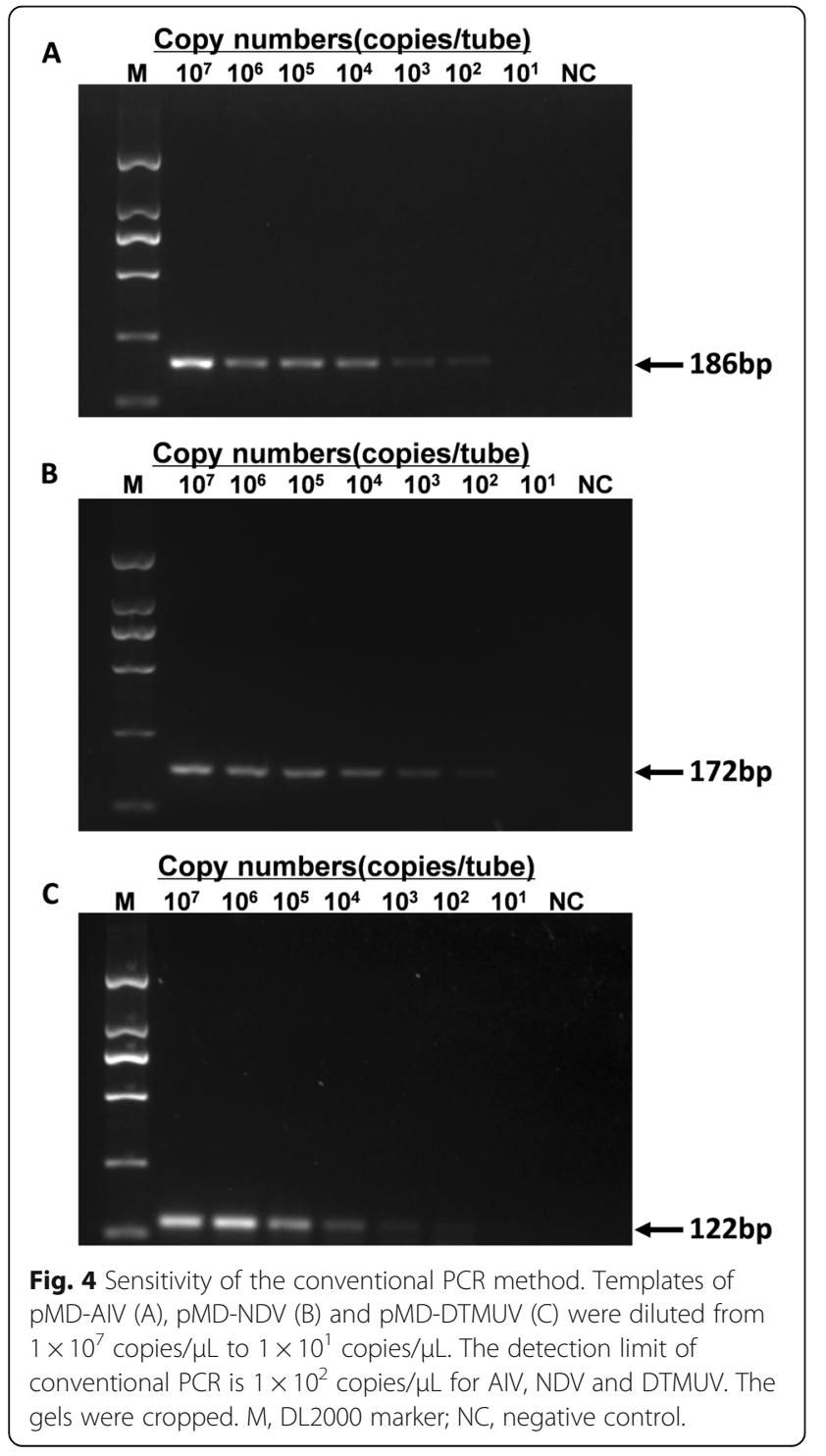

addition, to guarantee the high amplification efficiency of the developed method, D-optimal design was used to optimize the annealing temperature, primer or probe concentration. In this experiment, if a factor was considered to be critical, the level of the factor at the lowest $\mathrm{Ct}$ value would be used in the final experimental protocol [33]. When results conflict occurred, the favourable level of the factor was determined according to the number of minimum response parameters obtained and their economic applicability. Finally, with the necessary compromise, we obtained the ultimate optimum parameters.

Other viruses and bacteria that may infect ducks were utilized to evaluate the specificity of the triplex real-time PCR method. The results indicated that the primers and probes used in the assay produced neither crossreactions amongst the three viruses nor nonspecific reactions with other common duck pathogens when all the DNA templates existed in the sample pool. It is worth noting that our AIV primers and probes are designed on the M gene, so a variety of AIV subtypes can be detected. We used the triplex real-time PCR method to amplify H1-H11 AIV subtypes, and the results show that this method is suitable for the detection of these subtypes (Additional file 2).

As shown in the Fig. 5, the coefficient of determination $\left(R^{2}\right)$ was more than 0.99 in the range of $1 \times 10^{7}$ copies $/ \mu \mathrm{L}$ to $1 \times 10^{1}$ copies $/ \mu \mathrm{L}$, thereby indicating the quantitative range of this method. The $\mathrm{Ct}$ limit value was defined as the lowest copy number that gives a detectable PCR amplification product at least $95 \%$ of the time. When the concentration of AIV was diluted beyond 10 copies $/ \mu \mathrm{L}$, the correlation with the $\mathrm{Ct}$ value disappeared, the SD value of the experiment increased, and the $\mathrm{Ct}$ value fluctuated randomly between 34 and 36 . Based on these results, we chose a $\mathrm{Ct}$ value of 34 as the 


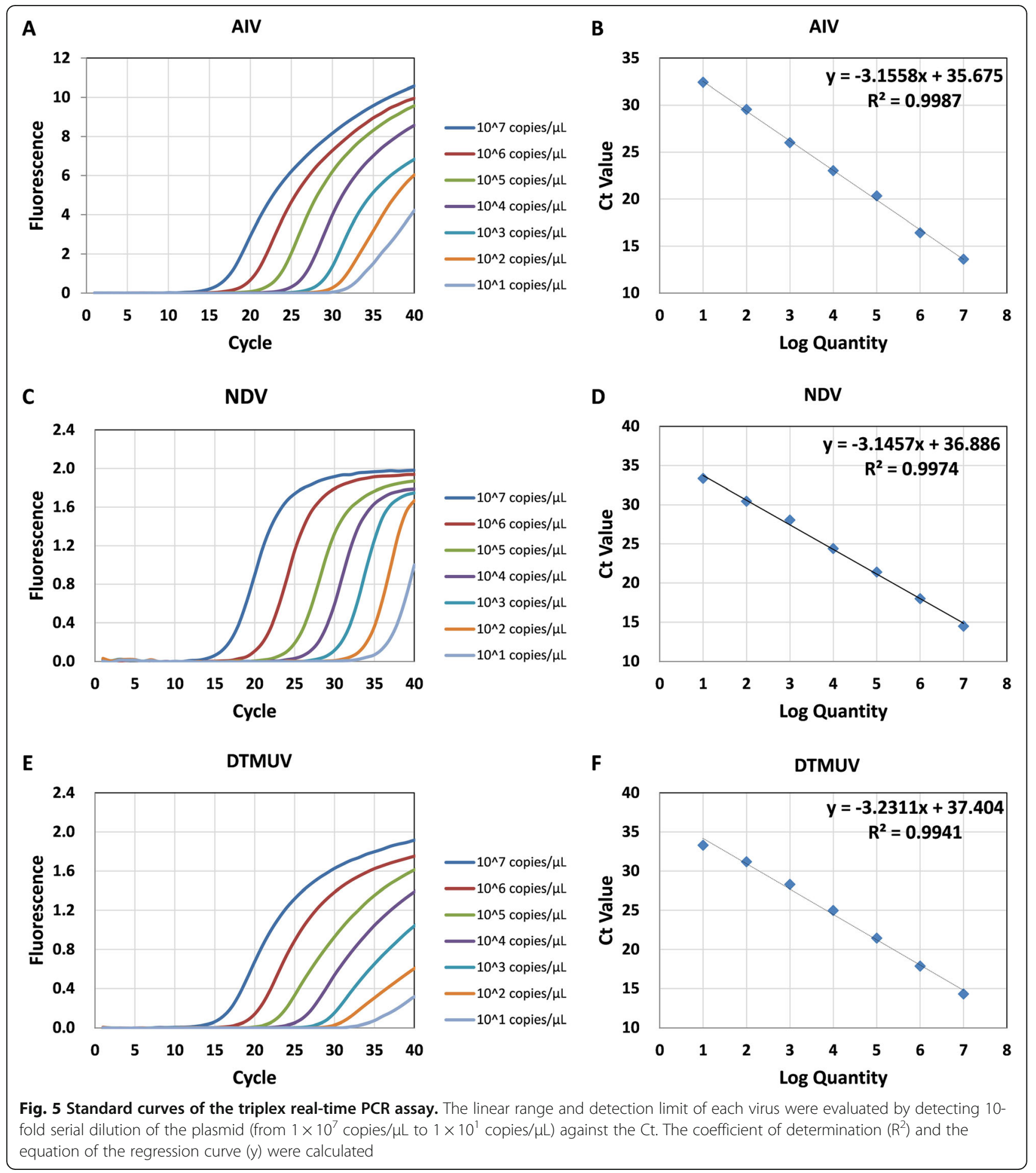

limit value for AIV, corresponding to a detection limit of $1 \times 10^{1}$ copies $/ \mu \mathrm{L}$. Similarly, the Ct limit value of NDV and DTMUV is 35 .

In fact, mixed infections of different pathogens at different concentrations are common in clinical practice [34]. When ducks are infected with one virus, the reduced immunity of the body makes them susceptible to other viruses [35], which also results in more serious economic losses [20]. Therefore, the coinfection models was used to determine the detection efficiency of mixed infection. The result demonstrated that the three viruses, at any combination of viruses' 
Table 2 Intra- and Inter- assay reproducibility of the triplex realtime PCR

\begin{tabular}{|c|c|c|c|c|c|c|c|}
\hline \multirow[t]{2}{*}{ Name } & \multirow{2}{*}{$\begin{array}{l}\text { Number } \\
\text { of DNA } \\
\text { Copies } \\
\text { (copies/ } \\
\mu \mathrm{L} \text { ) }\end{array}$} & \multicolumn{3}{|c|}{ Intra-assay } & \multicolumn{3}{|c|}{ Inter-assay } \\
\hline & & Mean & SD & CV (\%) & Mean & SD & CV (\%) \\
\hline \multirow[t]{3}{*}{ AIV } & $1 \times 10^{7}$ & 13.71 & 0.27 & 1.97 & 13.52 & 0.60 & 4.44 \\
\hline & $1 \times 10^{5}$ & 20.54 & 0.22 & 1.07 & 20.22 & 0.25 & 1.24 \\
\hline & $1 \times 10^{3}$ & 25.97 & 0.35 & 1.35 & 26.14 & 0.61 & 2.33 \\
\hline \multirow[t]{3}{*}{ NDV } & $1 \times 10^{7}$ & 14.72 & 0.07 & 0.48 & 14.64 & 0.27 & 1.84 \\
\hline & $1 \times 10^{5}$ & 21.44 & 0.31 & 1.45 & 21.50 & 0.34 & 1.58 \\
\hline & $1 \times 10^{3}$ & 28.11 & 0.35 & 1.25 & 27.90 & 0.76 & 2.72 \\
\hline \multirow[t]{3}{*}{ DTMUV } & $1 \times 10^{7}$ & 14.25 & 0.12 & 0.84 & 14.38 & 0.33 & 2.29 \\
\hline & $1 \times 10^{5}$ & 21.35 & 0.35 & 1.64 & 21.46 & 0.36 & 1.68 \\
\hline & $1 \times 10^{3}$ & 28.25 & 0.62 & 2.19 & 28.33 & 0.89 & 3.14 \\
\hline
\end{tabular}

concentration, could be determined, indicating that the triplex real-time PCR was accurate and applicable for clinical sample analysis.

In our previous study, we established uniplex and multiplex conventional PCR methods for the simultaneous detection of 7 viruses [36]. The detection limit of uniplex PCR for AIV, NDV and DTMUV is $1 \times 10^{1}$ copies $/ \mu \mathrm{L}, 1 \times 10^{1}$ copies $/ \mu \mathrm{L}, 1 \times 10^{2}$ copies $/ \mu \mathrm{L}$, respectively. However, the sensitivity of the multiplex PCR was not satisfactory, with a detection limit of $1 \times 10^{4}$ copies $/ \mu \mathrm{L}$ for these viruses. In addition, many PCR methods were established to detect these viruses $[37,38]$, with detection limits between $1 \times 10^{2}$ copies/ $\mu \mathrm{L}$ and $1 \times 10^{3}$ copies/ $\mu \mathrm{L}$ for different viruses. $\mathrm{Al}$ though these conventional PCR methods are cheap, they are less sensitive and require laborious post-PCR processing, which hinder its application in the sample analysis. Different from the conventional PCR, the real-time PCR method can monitor the amplification of the target in real time, with high sensitivity and fast speed. At present, a variety of uniplex real-time PCR methods have been established for the detection of these viruses, which can detect the minimum $2 \times$ $10^{1}$ copies $/ \mu \mathrm{L}$ of NDV [39] and $4 \times 10^{2}$ copies $/ \mu \mathrm{L}$ of DTMUV [40]. Some multiplex real-time PCR methods can distinguish various subtypes of AIV, with detection limits of $1 \times 10^{1}$ copies/ $\mu \mathrm{L}$ [41] or $1 \times 10^{3}$ copies/ $\mu \mathrm{L}$ [42]. Compared with the above methods, the realtime PCR method established in this experiment realizes the simultaneous detection of AIV, NDV and DTMUV, with a detection limit of $1 \times 10^{1}$ copies $/ \mu \mathrm{L}$, which is suitable for rapid detection of these viruses.

The developed method has been applied for a pilot study of clinical sample and all these viruses were found. It is worth noting that the analysis of the clinical sample indicates that the AIV positive infection rate in the Chinese live poultry market is high. This finding is consistent with the previous report, which showed that the AIV virus has been detected in live poultry market from time to time since the emergence of human infectious AIV in China in 2013 [43]. This situation highlights the need for virus surveillance. To this end, the method developed in the study has great practical value.

Table 3 The detection of the co-infection models by triplex real-time PCR

\begin{tabular}{|c|c|c|c|c|c|c|}
\hline \multirow{2}{*}{$\begin{array}{l}\text { Co-infection proportion } \\
\text { a }\end{array}$} & \multicolumn{3}{|c|}{ Number of DNA copies (copies/ $\mu \mathrm{L})$} & \multicolumn{3}{|c|}{ Co-infection real-time PCR Ct Value (mean \pm SD) ${ }^{\mathbf{b}}$} \\
\hline & AIV & NDV & DTMUV & AIV & NDV & DTMUV \\
\hline AIV:NDV:DTMUV = 10:1:1 & $1 \times 10^{7}$ & $1 \times 10^{6}$ & $1 \times 10^{6}$ & $13.66 \pm 0.13$ & $18.15 \pm 0.27$ & $18.15 \pm 0.27$ \\
\hline AIV:NDV:DTMUV = 10:5:1 & $1 \times 10^{7}$ & $5 \times 10^{6}$ & $1 \times 10^{6}$ & $13.50 \pm 0.28$ & $17.25 \pm 0.27$ & $18.03 \pm 0.16$ \\
\hline AIV:NDV:DTMUV = 1:5:10 & $1 \times 10^{6}$ & $5 \times 10^{6}$ & $1 \times 10^{7}$ & $16.58 \pm 0.22$ & $17.13 \pm 0.15$ & $14.54 \pm 0.28$ \\
\hline AIV:NDV = 1:1 & $1 \times 10^{7}$ & $1 \times 10^{7}$ & - & $13.28 \pm 0.48$ & $14.43 \pm 0.33$ & - \\
\hline AIV:NDV = 10:1 & $1 \times 10^{7}$ & $1 \times 10^{6}$ & - & $13.57 \pm 0.22$ & $18.25 \pm 0.23$ & - \\
\hline AIV:NDV = 100:1 & $1 \times 10^{7}$ & $1 \times 10^{5}$ & - & $13.93 \pm 0.10$ & $21.73 \pm 0.38$ & - \\
\hline AIV:DTMUV =1:1 & $1 \times 10^{7}$ & - & $1 \times 10^{7}$ & $13.43 \pm 0.32$ & - & $14.38 \pm 0.34$ \\
\hline AIV:DTMUV =10:1 & $1 \times 10^{7}$ & - & $1 \times 10^{6}$ & $13.57 \pm 0.29$ & - & $17.92 \pm 0.32$ \\
\hline AIV:DTMUV =100:1 & $1 \times 10^{7}$ & - & $1 \times 10^{5}$ & $13.24 \pm 0.34$ & - & $21.33 \pm 0.18$ \\
\hline NDV:DTMUV = 1:1 & - & $1 \times 10^{7}$ & $1 \times 10^{7}$ & - & $14.32 \pm 0.32$ & $14.53 \pm 0.22$ \\
\hline NDV:DTMUV = 10:1 & - & $1 \times 10^{7}$ & $1 \times 10^{6}$ & - & $14.49 \pm 0.19$ & $18.02 \pm 0.14$ \\
\hline NDV:DTMUV =100:1 & - & $1 \times 10^{7}$ & $1 \times 10^{5}$ & - & $14.54 \pm 0.15$ & $21.68 \pm 0.23$ \\
\hline
\end{tabular}

\footnotetext{
${ }^{a}$ There were two kinds of co-infection models included:the triplex co-infection and duplex co-infection
}

b The data was shown as the mean \pm SD $(n=3)$

-: represents no design in the corresponding system 
Table 4 Results of the clinical positive samples detected by triplex real-time PCR, conventional PCR and virus isolation

\begin{tabular}{|c|c|c|c|c|c|c|c|c|c|}
\hline \multirow{2}{*}{$\begin{array}{l}\text { Positive } \\
\text { samples }\end{array}$} & \multicolumn{3}{|l|}{ AIV } & \multicolumn{3}{|l|}{ NDV } & \multicolumn{3}{|l|}{ DTMUV } \\
\hline & $\begin{array}{l}\text { triplex real-time } \\
\text { PCR }\end{array}$ & $\begin{array}{l}\text { Conventional } \\
\text { PCR }\end{array}$ & $\begin{array}{l}\text { Virus } \\
\text { isolation }\end{array}$ & $\begin{array}{l}\text { triplex real-time } \\
\text { PCR }\end{array}$ & $\begin{array}{l}\text { Conventional } \\
\text { PCR }\end{array}$ & $\begin{array}{l}\text { Virus } \\
\text { isolation }\end{array}$ & $\begin{array}{l}\text { triplex real-time } \\
\text { PCR }\end{array}$ & $\begin{array}{l}\text { Conventional } \\
\text { PCR }\end{array}$ & $\begin{array}{l}\text { Virus } \\
\text { isolation }\end{array}$ \\
\hline 1 & + & + & + & - & - & - & - & - & - \\
\hline 2 & + & + & + & - & - & - & - & - & - \\
\hline 3 & + & + & + & - & - & - & - & - & - \\
\hline 4 & + & + & + & - & - & - & - & - & - \\
\hline 5 & + & + & + & - & - & - & - & - & - \\
\hline 6 & + & + & + & - & - & - & - & - & - \\
\hline 7 & + & + & + & - & - & - & - & - & - \\
\hline 8 & + & + & + & - & - & - & - & - & - \\
\hline 9 & + & + & + & - & - & - & - & - & - \\
\hline 10 & + & + & + & - & - & - & - & - & - \\
\hline 11 & + & + & + & - & - & - & - & - & - \\
\hline 12 & + & + & + & + & + & + & - & - & - \\
\hline 13 & + & + & + & + & + & + & - & - & - \\
\hline 14 & + & - & + & - & - & - & - & - & - \\
\hline 15 & + & - & + & - & - & - & - & - & - \\
\hline 16 & + & - & + & - & - & - & - & - & - \\
\hline 17 & + & - & - & - & - & - & - & - & - \\
\hline 18 & - & + & - & - & - & - & - & - & - \\
\hline 19 & - & + & - & - & - & - & - & - & - \\
\hline 20 & - & + & - & - & - & - & - & - & - \\
\hline 21 & - & + & - & - & - & - & - & - & - \\
\hline 22 & - & + & - & - & - & - & - & - & - \\
\hline 23 & - & - & - & + & + & + & - & - & - \\
\hline 24 & - & - & - & + & + & + & - & - & - \\
\hline 25 & - & - & - & + & + & + & - & - & - \\
\hline 26 & - & - & - & + & - & + & - & - & - \\
\hline 27 & - & - & - & + & + & - & - & - & - \\
\hline 28 & - & - & - & - & + & - & - & - & - \\
\hline 29 & - & - & - & - & - & - & + & + & + \\
\hline 30 & - & - & - & - & - & - & + & + & + \\
\hline 31 & - & - & - & - & - & - & + & + & + \\
\hline $\begin{array}{l}\text { Positive } \\
\text { rates } \\
(\%)\end{array}$ & $\begin{array}{l}14.17 \\
(17 / 120)\end{array}$ & $\begin{array}{l}15.00 \\
(18 / 120)\end{array}$ & $\begin{array}{l}13.33(16 / \\
120)\end{array}$ & $\begin{array}{l}5.83 \\
(7 / 120)\end{array}$ & $\begin{array}{l}5.83 \\
(7 / 120)\end{array}$ & $\begin{array}{l}5.00 \\
(6 / 120)\end{array}$ & $\begin{array}{l}7.50 \\
(3 / 40)\end{array}$ & $\begin{array}{l}7.50 \\
(3 / 40)\end{array}$ & $\begin{array}{l}7.50 \\
(3 / 40)\end{array}$ \\
\hline
\end{tabular}

\section{Conclusion}

The multiplex real-time PCR described here provides a novel tool for routine diagnosis and epidemiological surveillance of three viruses, AIV, NDV, and DTMUV by allowing rapid detection and quantification of these viruses in the clinical field.

\section{Methods}

Pathogens and clinical samples

For specificity testing, the nucleic acids of $\operatorname{AIV}(\mathrm{H} 1-\mathrm{H} 11)$, NDV, DTMUV, APMV-4, APMV-6, APMV-8, APMV-9, EDSV, DHAV, DEV, GPV, FAdV, E. coli, SE, RA, Pasteurella multocida and Clostridium perfringens were used in the study. More details of these pathogens are in the Additional file 3.

With the permission of animal owners and relevant managers, we collected 40 samples (20 tissue specimens and 20 
Table 5 Clinical performance of triplex real-time PCR and conventianal PCR

\begin{tabular}{llllllllll}
\hline Virus & \multicolumn{7}{l}{ Triplex real-time PCR asssay } \\
\cline { 2 - 10 } & TP & FN & TN & FP & Tatal & $\begin{array}{l}\text { Sensitivity } \\
(\%)\end{array}$ & Specificity(\%) & Positive predictive value(\%) & Negative predictive value(\%) \\
\hline AIV & 16 & 0 & 103 & 1 & 120 & 100.00 & 99.04 & 94.12 & 100.00 \\
NDV & 6 & 0 & 113 & 1 & 120 & 100.00 & 99.13 & 85.71 & 100.00 \\
DTMUV & 3 & 0 & 37 & 0 & 40 & 100.00 & 100.00 & 100.00 & 100.00 \\
Virus & Conventional PCR methods & & & & Negative predictive value(\%) \\
& TP & FN & TN & FP & Tatal & Sensitivity(\%) & Specificity(\%) & Positive predictive value(\%) & 97.06 \\
AIV & 13 & 3 & 99 & 5 & 120 & 81.25 & 95.19 & 72.22 & 99.12 \\
NDV & 5 & 1 & 112 & 2 & 120 & 83.33 & 98.25 & 71.43 & 100.00 \\
DTMUV & 3 & 0 & 37 & 0 & 40 & 100.00 & 100.00 & 100.00 &
\end{tabular}

${ }^{a}$ TP: true positive, FN: false negative, TN: true negative, FP: false positive

throat swabs) at the Nanjing Tianyin Mountain Agricultural Trade Market on October 17, 2018 and 80 samples (40 tissue specimens and 40 throat swabs) at the Jiangsu Yancheng Wetland National Nature Reserve on November 15,2018 . At the same time, fifty negative samples (25 tissue specimens and 25 throat swabs) were collected from these two locations, which were confirmed to be free of AIV, NDV and DTMUV on real-time PCR [44-46]. All the samples were transported at $-40^{\circ} \mathrm{C}$ and kept at $-80^{\circ} \mathrm{C}$ for long-term storage. The homogenized tissue specimens and throat swabs were centrifuged at $6000 \times \mathrm{g}$ for $5 \mathrm{~min}$ at $4{ }^{\circ} \mathrm{C}$.

An aliquot of the supernatant of all samples was used to extract proviral RNA, and then reverse transceibed into cDNA, which was utilized as a template for triplex real-time PCR and conventional PCR detection [36]. The remaining supernatant was passed through $0.45-\mathrm{m}$ filters to carry out virus isolation. All viruses were propagated in 9- to 11-day-old specific pathogen-free (SPF) embryonated chicken eggs and harvested from amnioallantoic fluids or tissues of inoculated eggs.

\section{RNA extraction and CDNA synthesis}

The nucleic acid of AIV, NDV, and DTMUV was extracted by Viral RNA Extraction Kit (Sangon Biotech,
China), and then reverse transcribed into cDNA by Reverse Transcription Kit (Thermo Scientific, USA), according to the manufacturer's instructions. Finally, the concentration and purity of each genome were determined by spectrophotometry (Thermo Scientific, USA) and preserved at $-20^{\circ} \mathrm{C}$.

\section{Primer and probe design}

The complete gene sequences of AIV, NDV and DTMUV strains were downloaded from GenBank, and the viral gene sequences were aligned using DNAMAN (LynnonBiosoft, USA) to find gene conserved regions. The target genes including Matrix $(\mathrm{M})$ gene for AIV, Fusion (F) gene for NDV and Envelope (E) gene for DTMUV were highly conserved (Table 6). We designed three pairs of specific primers and probes for each virus using Primer Premier 5 (Premier, Canada) in accordance with the results of sequence alignment. The fluorescent reporter dyes FAM, JOE and ROX were labeled at the $5^{\prime}$ end of the three viruses, and BHQ1, BHQ1, and BHQ2 were linked at the $3^{\prime}$ end for the simultaneous detection of the three genes in a single reaction (Table 6). The primers were synthesized by Nanjing Kingsley Biotechnology Co. Ltd.

Table 6 Primers and Probes

\begin{tabular}{|c|c|c|c|c|}
\hline Name $^{a}$ & Sequence $\left(5^{\prime}-3^{\prime}\right)^{\mathbf{b}}$ & Genomic region & Target genes & Amplicon size(bp) \\
\hline AIV-F & AGGGTTTGTGTTCACGCTC & 180-198 & & 186 \\
\hline AIV-R & CCGGTTGAGTAGCTGAGTGC & $346-365$ & M & \\
\hline AIV-P & ROX - CCGTGCCCAGTGAGCGAGGAC - BHQ1 & $210-233$ & & \\
\hline NDV-F & GACTCAACTCTTGGGCATACA & $837-857$ & & 172 \\
\hline NDV-R & TGAGGTGTCAAGCTCTTCTAT & $988-1008$ & $\mathrm{~F}$ & \\
\hline NDV-P & FAM - CAGTCGGGAACCTAAATAATATGCGTGC - BHQ-1 & $872-899$ & & \\
\hline DTMUV-F & CAGAGACTGGTTTCATGA & $642-659$ & & 122 \\
\hline DTMUV-R & AAGCCACCACTGATTGTT & $746-763$ & E & \\
\hline DTMUV-P & JOE - TTACCATGGACAGGGTCATCAGC - BHQ-2 & $667-689$ & & \\
\hline
\end{tabular}

${ }^{a} \mathrm{~F}$ : forward primer, R: reverse primer, $\mathrm{P}$ : TaqMan probe

${ }^{b}$ ROX: 6-carboxy-x-rhodamine, FAM: 6-carboxy-fluorescein, BHQ-1:Black Hole Quencher 1, BHQ-2: Black Hole Quencher 


\section{Standard plasmid preparation}

Specific target fragments were amplified with the primers (Table 6), and then cloned into the pMD-18 T vector (TaKaRa, China) to obtain the recombinant plasmids pMD-AIV, pMD-NDV, and pMD-DTMUV. The copy number of the recombinant plasmids was calculated using the following formula: copy number (copies/ $\mu \mathrm{L})=\mathrm{NA} \quad($ copies $/ \mathrm{mol}) \times$ concentration $(\mathrm{g} / \mu \mathrm{L}) / \mathrm{MW} \quad(\mathrm{g} /$ mol), where NA is Avogadro's number and MW is the base number times 340 [47].

\section{Experimental design for the real-time PCR method}

The real-time PCR method was first optimized using a Doptimal design consisting of 16 experiments. Three factors with three levels each were considered. These factors include annealing temperature (from $53^{\circ} \mathrm{C}$ to $60^{\circ} \mathrm{C}$ ), primer concentration for each target gene (from $0.2 \mu \mathrm{M}$ to $0.6 \mu \mathrm{M}$ ), and probes for each target gene (from $0.05 \mu \mathrm{M}$ to $0.2 \mu \mathrm{M})$. The Ct value was used in statistical analysis. All analyses were performed using MODDE 12.1 software (Umetrics, Sweden). The relationship between the response $Y$ and the variables $X_{i}, X_{j}$ was expressed as $Y=\beta_{0}+$ $\beta_{\mathrm{i}} \mathrm{X}_{\mathrm{i}}+\beta_{\mathrm{j}} \mathrm{X}_{\mathrm{j}}+\beta_{\mathrm{ij}} \mathrm{X}_{\mathrm{i}} \mathrm{X}_{\mathrm{j}}+\beta_{\mathrm{ii}} \mathrm{X}_{\mathrm{i}}^{2}+\beta_{\mathrm{jj}} \mathrm{X}_{\mathrm{j}}^{2}+. . . \varepsilon$, where $\beta_{\mathrm{s}}$ were the regression coefficients and $\varepsilon$ was the experimental error. The linear coefficients $\beta_{\mathrm{i}}$ and $\beta_{\mathrm{j}}$ were the quantitative effect of the respective variables. The cross coefficient $\beta_{\mathrm{ij}}$ measured the interaction between the variables, and the square terms of $\beta_{\mathrm{ii}} \mathrm{X}_{\mathrm{i}}^{2}$ and $\beta_{\mathrm{jj}} \mathrm{X}_{\mathrm{j}}^{2}$ described the nonlinear effects on the response [21]. Then we explored the effects of different annealing temperature, primer and probe concentration on the fluorescence signal. The conditions with the smallest $\mathrm{Ct}$ value and highest fluorescence signal were set as the optimal reaction conditions .

\section{Real-time PCR method}

The real-time PCR was determined in a $20.0 \mu \mathrm{L}$ reaction system with a LightCycler 96 real-time PCR system (Roche, Switzerland). The ingredients were $10.0 \mu \mathrm{L}$ of TaKaRa Premix Ex Taq ${ }^{\text {Tux }}$ (Probe real-time PCR), $0.5 \mu \mathrm{M}$ of the primers for AIV, NDV and DTMUV genes, $0.1 \mu \mathrm{M}$ of the probes, and $1.0 \mu \mathrm{L}$ of template. The PCR program was set as follows: pre-denaturation at $95^{\circ} \mathrm{C}$ for $2 \mathrm{~min}$ and 40 amplification cycles of $95^{\circ} \mathrm{C}$ for $10 \mathrm{~s}$ and $54{ }^{\circ} \mathrm{C}$ for $30 \mathrm{~s}$. Multiple fluorescent signals were obtained once per cycle upon the completion of the extension step. The standard plasmid pMD-AIV, pMD-NDV and pMD-DTMUV were used as the positive control, $\mathrm{dd}_{2} \mathrm{O}$ as the negative control. The assay was repeated at least three times within the study.

\section{Conventional PCR method}

Conventional PCR assay was conducted in a $20.0 \mu \mathrm{L}$ reaction system, which containing $10.0 \mu \mathrm{L}$ of $2 \times$ Taq Master Mix (Vazyme Biotech, USA), $0.5 \mu \mathrm{M}$ of the primers for AIV, NDV, and DTMUV respectively, $1.0 \mu \mathrm{L}$ of template and $\mathrm{ddH}_{2} \mathrm{O}$ to a final volume of $20.0 \mu \mathrm{L}$. The amplification programme was that, pre-denaturation at $95^{\circ} \mathrm{C}$ for $5 \mathrm{~min}$, followed by 40 cycles of sequentially denaturation at $95^{\circ} \mathrm{C}$ for $30 \mathrm{~s}$, annealing at $54^{\circ} \mathrm{C}$ for $30 \mathrm{~s}$ and extension at $72{ }^{\circ} \mathrm{C}$ for $20 \mathrm{~s}$, a final extension at $72{ }^{\circ} \mathrm{C}$ for 10 min. The PCR products were analysed by $1.5 \%$ agarose gel electrophoresis. $\mathrm{ddH}_{2} \mathrm{O}$ was used as negative control.

\section{Validation of the real-time PCR method}

The specificity of the triplex real-time PCR was evaluated by cross-reactivity with other duck viruses and bacteria (including APMV-4, APMV-6, APMV-8, APMV-9, EDSV, DHAV, DEV, GPV, FAdV, Escherichia coli, SE, RA, Pasteurella multocida and Clostridium perfringens). The standard plasmid DNAs were 10 -fold serially diluted from $1 \times 10^{7}$ copies $/ \mu \mathrm{L}$ to $1 \times 10^{1}$ copies $/ \mu \mathrm{L}$ for each virus to determine the detection limit of the triplex real-time PCR method. In addition, standard plasmids in three different concentrations $\left(1 \times 10^{7}, 1 \times 10^{5}\right.$ and $1 \times$ $10^{3}$ copies $/ \mu \mathrm{L}$ ) were used as templates to evaluate the repeatability and reproducibility of the real-time PCR method. The coefficients of variation $(\mathrm{CV})$ for the $\mathrm{Ct}$ values of the intra- and inter-assay comparisons were determined by testing three replicates of each concentration in a single round of real-time PCR or by repeating three rounds of real-time PCR.

\section{Pilot study of the real-time PCR method}

To evaluated whether the triplex assay could be used as a diagnostic tool in surveillance programs, the coinfection models were first designed to determine the detection efficiency of the developed method. Then, a total of 120 clinical samples were assayed to evaluated the feasibility of the triplex real-time PCR method. The results were further validated by published conventional PCR as well as virus isolation. Using virus isolation as the gold standard, the sensitivity, specificity, positive predictive value and negative predictive value of the three virus detected by real-time PCR and conventional PCR were calculate $[39,48,49]$.

\section{Supplementary information}

Supplementary information accompanies this paper at https://doi.org/10. 1186/s12917-020-02399-z.

\section{Additional file 1.}

Additional file 2.

Additional file 3.

\section{Abbreviations}

AIV: avian influenza virus; NDV: Newcastle disease virus; DTMUV: duck Tembusu virus; APMV-4: Avian paramyxovirus 4; APMV-6: Avian paramyxovirus 6; APMV-8: Avian paramyxovirus 8; APMV-9: Avian paramyxovirus 9; DHAV: Duck hepatitis A virus; DEV: Duck enteritis virus; 
GPV: Goose parvovirus; FAdV: Fowl adenovirus; EDSV: Duck egg drop syndrome virus; E.coli: Escherichia coli; C.perfringens: Clostridium perfringens; $P$. multocida: Pasteurella multocida; SE: Salmonella; RA: Riemerella anatipestifer; ELISA: Enzyme-linked immune sorbent assay; PCR: Polymerase Chain Reaction; M: DL2000 marker; NC: negative control; NA: Avogadro's number; $\mathrm{MW}$ : base number times; $\mathrm{ddH}_{2} \mathrm{O}$ : double distilled water; FAO: Food and Agriculture Organization

\section{Acknowledgements}

Not applicable.

\section{Authors' contributions}

LPY designed the study and approved the manuscript. XYZ and MY developed the triplex real-time PCR method and wrote the manucript. DNX, YFG and ZHT analyzed data and collected clinical samples. YL revised the manuscript. All authors read and approved the final manuscript.

\section{Funding}

The clinical samples collection was supported by the National Key Research and Development Program (2016YFD0500800) and Key Program of Science and Technology Planning of Guangdong Province (2017B020202010). The analysis and interpretation of data was supported by Forestry Science and Technology Innovation and Promotion Project of Jiangsu Province (LYKJ [2018]22) and State Key Laboratory for Managing Biotic and Chemical Threats to the Safety of Agro-products (KF20190109). The writing of the manuscript was supported by Priority Academic Program Development of Jiangsu Higher Education Institutions.

\section{Availability of data and materials}

All data generated or analyzed during this study are included in this published article and its Additional files.

\section{Ethics approval and consent to participate}

This study was performed in accordance with the recommendations in the Guide for the Care and Use of Laboratory Animals of the Ministry of Health, China. All animal welfare and experimental procedures were in accordance with the approval of the ethical regulations of Nanjing Agricultural University (Permission Number: SYXK (Su) 2017-0007).

\section{Consent for publication}

Not applicable.

\section{Competing interests}

The authors declare that they have no competing interests.

\section{Author details}

${ }^{1}$ College of Veterinary Medicine, Nanjing Agricultural University, Nanjing 210095, China. ${ }^{2}$ MOE Joint International Research Laboratory of Animal Health and Food Safety, Nanjing Agricultural University, Nanjing 210095, China. ${ }^{3}$ Guangdong Province Key Laboratory of Waterfowl Healthy Breeding, Zhongkai University of Agricultural and Engineering, Guangzhou 510225, China. ${ }^{4}$ Administration for Market Regulation of Guangdong Province Key Laboratory of Supervision for Edible Agricultural Products, Shenzhen Centre of Inspection and Testing for Agricultural Products, Shenzhen 518000, China. ${ }^{5}$ Jofunhwa Biotechnology (Nanjing) Co., Ltd, Nanjing 211102, China.

Received: 23 December 2019 Accepted: 1 June 2020

Published online: 19 June 2020

\section{References}

1. Haider N, Sturm-Ramirez K, Khan SU, Rahman MZ, Sarkar S, Poh MK, Shivaprasad HL, Kalam MA, Paul SK, Karmakar PC. Unusually high mortality in waterfowl caused by highly pathogenic avian influenza a(H5N1) in Bangladesh. Transboundary \& Emerging Diseases. 2017;64(1):144-56.

2. Kwon YK, Joh SJ, Kim MC, Sung HW, Lee YJ, Choi JG, Lee EK, Kim JH. Highly pathogenic avian influenza (H5N1) in the commercial domestic ducks of South Korea. Avian Pathol. 2005;34(4):367-70.

3. Scheibner D, Blaurock C, Mettenleiter TC, Abdelwhab EM. Virulence of three European highly pathogenic H7N1 and H7N7 avian influenza viruses in Pekin and Muscovy ducks. BMC Vet Res. 2019;15(1):142.
4. Chatziprodromidou IP, Arvanitidou M, Guitian J, Apostolou T, Vantarakis G, Vantarakis A. Global avian influenza outbreaks 2010-2016: a systematic review of their distribution, avian species and virus subtype. Syst Rev. 2018; 7(1):17.

5. Peng Y, Xie ZX, Liu JB, Pang YS, Deng XW, Xie ZQ, Xie LJ, Fan Q, Luo SS. Epidemiological surveillance of low pathogenic avian influenza virus (LPAIV) from poultry in Guangxi Province, Southern China. PLoS One. 2013;8(10): e77132.

6. Kaleta EF, Hergarten G, Yilmaz A. Avian influenza a viruses in birds --an ecological, ornithological and virological view. Dtsch Tierarztl Wochenschr. 2005;112(12):448-56.

7. Shengbin G, Yunling Z, Jiarong Y, Xiaoyu W, Dongxia Z, Yumei C, Hualei L, Zhiliang W. Comparison between class I NDV and class II NDV in aerosol transmission under experimental condition. Poult Sci. 2019;98(10):5040-44.

8. Taubenberger JK, Kash JC. Influenza virus evolution, host adaptation, and pandemic formation. Cell Host Microbe. 2010;7(6):440-51.

9. Dai YB, Cheng X, Liu M, Shen XY, Li JM, Yu SQ, Zou JM, Ding C. Experimental infection of duck origin virulent Newcastle disease virus strain in ducks. BMC Vet Res. 2014;10:164.

10. Shen HQ, Lin WC, Wang ZX, Zhang K, Yan ZQ, Zhou QF, Qin JP, Xie QM, Bi YZ, Chen F. Pathogenicity and genetic characterization of a duck Tembusu virus associated with egg-dropping in Muscovy ducks. Virus Res. 2016;223:52-6.

11. Aldous EW, Alexander DJ. Detection and differentiation of Newcastle disease virus (avian paramyxovirus type 1). Avian Pathol. 2001;30(2):117-28.

12. Hotta K, Takakuwa H, Yabuta T, Ung TTH, Usui T, Hang LKN, Le TT, Le MQ, Yamaguchi T, Otsuki K. Antibody survey on avian influenza viruses using egg yolks of ducks in Hanoi between 2010 and 2012. Vet Microbiol. 2013; 166(1-2):179-83.

13. Li X, Li G, Teng Q, Yu L, Wu X, Li Z. Development of a blocking ELISA for detection of serum neutralizing antibodies against newly emerged duck Tembusu virus. PLoS One. 2012;7(12):e53026.

14. Liu WQ. Establishment of multiple RT-PCR diagnostic techniques for avian influenza virus (AIV), Newcastle disease virus (NDV), classical swine fever virus (CSFV) and food and mouth disease virus (FMDV). Journal of Agricultural Biotechnology. 2005;2(3):161-5.

15. Nagarajan S, Rajukumar K, Tosh C, Ramaswamy V, Purohit K, Saxena G, Behera P, Pattnaik B, Pradhan HK, Dubey SC. Isolation and pathotyping of H9N2 avian influenza viruses in Indian poultry. Vet Microbiol. 2009;133(1-2): 154-63.

16. Smith TF, Uhl JR, Espy MJ, Sloan LM, Vetter EA, Jones MF, Rosenblatt JE, lii FRC. Development, implementation, and trend analysis of real-time PCR tests for the clinical microbiology laboratory. Clin Microbiol Newsl. 2004; 26(19):145-53.

17. Alsahami AA, Ideris A, Omar A, Ramanoon SZ, Sadiq MB. Isolation, identification and molecular characterization of Newcastle disease viruses in vaccinated chickens from commercial farms in the Sultanate of Oman. Int J Vet Sci Med. 2018;6(2):248-52.

18. Fereidouni SR, Aghakhan M, Werner O, Starick E, Bozorghmehrifard MH. Isolation and identification of avian influenza viruses from migratory birds in Iran. Vet Rec. 2005;157(17):526.

19. Wang Q, Wen Y, Yifan H, Wu Y, Cai Y, Xu L, Wang C, Li A, Wu B, Chen J. Isolation and identification of duck tembusu virus strain $\mathrm{IH}$ and development of latex-agglutination diagnostic method for rapid detection of antibodies. Avian Dis. 2014;58(4):616-22.

20. Qi G, Bingling Y, Qi W, Lili J, Haibo Z, Yanni G, Liting Q, Yongqiang W, Xiaole Q, Honglei G. Development and application of a multiplex PCR method for rapid differential detection of subgroup a, B, and J avian leukosis viruses. J Clin Microbiol. 2014;52(1):37-44.

21. Yue F, Cui S, Zhang C, Yoon KJ. A multiplex PCR for rapid and simultaneous detection of porcine circovirus type 2, porcine parvovirus, porcine pseudorabies virus, and porcine reproductive and respiratory syndrome virus in clinical specimens. Virus Genes. 2009;38(3):392-7.

22. Zhang A, Jin M, Liu F, Guo X, Hu Q, Han L, Tan Y, Chen H. Development and evaluation of a DAS-ELISA for rapid detection of avian influenza viruses. Avian Dis. 2006;50(3):325-30.

23. Liu J, Li Y, Liu A, Guan G, Xie J, Yin H, Luo J. Development of a multiplex PCR assay for detection and discrimination of Theileria annulata and Theileria sergenti in cattle. Parasitol Res. 2015;114(7):2715-21.

24. Doumanova L, Alexandrov M. Detection and identification of the Newcastle disease virus infection by electron and immunoelectron microscopy. Acta Virol. 1997;41(2):111-4. 
25. Chen S, Wang S, Li Z, Lin F, Cheng X, Zhu X, Wang J, Chen S, Huang M, Zheng $\mathrm{M}$. Isolation and characterization of a Chinese strain of Tembusu virus from Hy-line Brown layers with acute egg-drop syndrome in Fujian, China. Arch Virol. 2014;159(5):1099-107.

26. Luo X, Liu Y, Jia R, Shen H, Wang X, Wang M, Zhu D, Chen S, Liu M, Zhao X, et al. Ultrastructure of duck Tembusu virus observed by electron microscopy with negative staining. Acta Virol. 2018;62(3):330-2.

27. Mackay IM. Real-time PCR in the microbiology laboratory. Clinical Microbiology \& Infection. 2004;10(3):190-212.

28. Mackay IM, Arden KE, Andreas N. Real-time PCR in virology. Nucleic Acids Res. 2002;30(6):1292-305.

29. Espy MJ, Uhl JR, Sloan LM, Buckwalter SP, Jones MF, Vetter EA, Yao JDC, Wengenack NL, Rosenblatt JE, Cockerill FR. Real-time PCR in clinical microbiology: applications for routine laboratory testing. Clin Mcrobiol. 2006;19(1):165-256.

30. Chen HT, Zhang J, Sun DH, Zhang JL, Cai XP, Liu XT, Ding YZ, Ma LN, Yang $\mathrm{SH}$, Jin $\mathrm{L}$, et al. Rapid discrimination of $\mathrm{H} 5$ and $\mathrm{H} 9$ subtypes of avian influenza viruses and Newcastle disease virus by multiplex RT-PCR. Vet Res Commun. 2008:32(6):491-8.

31. Chang HK, Park JH, Song MS, Oh TK, Kim SY, Kim CJ, Kim H, Sung MH, Han HS, Hahn YS, et al. Development of multiplex rt-PCR assays for rapid detection and subtyping of influenza type a viruses from clinical specimens. J Microbiol Biotechnol. 2008;18(6):1164-9.

32. Tang Q, Wang J, Bao J, Sun H, Sun Y, Liu J, Pu J. A multiplex RT-PCR assay for detection and differentiation of avian $\mathrm{H} 3, \mathrm{H} 5$, and $\mathrm{H} 9$ subtype influenza viruses and Newcastle disease viruses. J Virol Methods. 2012;181(2):164-9.

33. Liu Y, Liu Q, Hesketh J, Huang D, Gan F, Hao S, Tang S, Guo Y, Huang K. Protective effects of selenium-glutathione-enriched probiotics on CCl4induced liver fibrosis. J Nutr Biochem. 2018;58:138-49.

34. Zhang X, Jiang S, Wu J, Zhao Q, Sun Y, Kong Y, Li X, Yao M, Chai T. An investigation of duck circovirus and co-infection in Cherry Valley ducks in Shandong Province, China. Vet Microbiol. 2009;133(3):252-6.

35. Pantin-Jackwood MJ, Costa-Hurtado M, Miller PJ, Afonso CL, Spackman E, Kapczynski DR, Shepherd E, Smith D, Swayne DE. Experimental co-infections of domestic ducks with a virulent Newcastle disease virus and low or highly pathogenic avian influenza viruses. Vet Microbiol. 2015;177(1-2):7-17.

36. Yao M, Zhang X, Gao Y, Song S, Xu D, Yan L. Development and application of multiplex PCR method for simultaneous detection of seven viruses in ducks. BMC Vet Res. 2019;15(1):103.

37. Xie Z, Luo S, Xie L, Liu J, Pang Y, Deng X, Xie Z, Fan Q, Khan Ml. Simultaneous typing of nine avian respiratory pathogens using a novel GeXP analyzer-based multiplex PCR assay. J Virol Methods. 2014;207:188-95.

38. Wang Y, Zhu S, Hong W, Wang A, Zuo W. A multiplex PCR for detection of six viruses in ducks. J Virol Methods. 2017;248:172-6.

39. Jang J, Hong $\mathrm{SH}$, Kim $\mathrm{H}$. Validation of a real-time RT-PCR method to quantify Newcastle disease virus (NDV) titer and comparison with other quantifiable methods. J Microbiol Biotechnol. 2011;21(1):100-8.

40. Liu Z, Fu Y, Ji Y, Wei J, Cai X, Zhu Q. Development and validation of onestep SYBR green real-time RT-PCR for the rapid detection of newly emerged duck Tembusu virus. Avian Dis. 2013;57(3):595-601

41. Liu J, Yao L, Zhai F, Chen Y, Lei J, Bi Z, Hu J, Xiao Q, Song S, Yan L, et al. Development and application of a triplex real-time PCR assay for the simultaneous detection of avian influenza virus subtype H5, H7 and H9. J Virol Methods. 2018;252:49-56.

42. Spackman E, Senne DA, Myers TJ, Bulaga LL, Garber LP, Perdue ML, Lohman K, Daum LT, Suarez DL. Development of a real-time reverse transcriptase PCR assay for type a influenza virus and the avian $\mathrm{H} 5$ and H7 hemagglutinin subtypes. J Clin Microbiol. 2002;40(9):3256-60

43. Jiang WM, Hou GY, Li JP, Peng C, Wang SC, Liu S, Zhuang QY, Chen JM, Liu $\mathrm{HL}$. Prevalence of H7N9 subtype avian influenza viruses in poultry in China, 2013-2018. Transbound Emerg Dis. 2019;66(4):1758-61.

44. Spackman E. Avian influenza virus detection and quantitation by real-time RT-PCR. Methods Mol Biol. 2014;1161:105-18.

45. Yan L, Yan P, Zhou J, Teng Q, Li Z. Establishing a TaqMan-based real-time PCR assay for the rapid detection and quantification of the newly emerged duck Tembusu virus. Virol J. 2011:8:464.

46. Wise MG, Suarez DL, Seal BS, Pedersen JC, Senne DA, King DJ, Kapczynski DR, Spackman E. Development of a real-time reverse-transcription PCR for detection of Newcastle disease virus RNA in clinical samples. J Clin Microbiol. 2004;42(1):329-38.
47. Niu X, Chen H, Yang J, Yu X, Ti J, Wang A, Diao Y. Development of a TaqMan-based real-time PCR assay for the detection of novel GPV. J Virol Methods. 2016;237:32-7.

\section{Publisher's Note}

Springer Nature remains neutral with regard to jurisdictional claims in published maps and institutional affiliations.
Ready to submit your research? Choose BMC and benefit from:

- fast, convenient online submission

- thorough peer review by experienced researchers in your field

- rapid publication on acceptance

- support for research data, including large and complex data types

- gold Open Access which fosters wider collaboration and increased citations

- maximum visibility for your research: over $100 \mathrm{M}$ website views per year

At $\mathrm{BMC}$, research is always in progress.

Learn more biomedcentral.com/submissions 